DOI: $10.21802 / \operatorname{artm} .2021 .2 .18 .20$.

UDC 616.127-005.8+616.035.1

\title{
EFFICACY OF TRIMETAZIDINE IN PATIENTS WITH ACUTE CORONARY SYNDROMES AND CO-MORBIDITIES
}

\author{
I.P. Vakaliuk, Iyad Alghzawi
}

Ivano-Frankivsk National Medical University, Department of Internal Medicine No2 and Nursing, Ivano-Frankivsk, Ukraine, ORCID ID: 0000-0002-4430-6816, ORCID ID: 0000-0002-4280-917X, e-mail: eyadeyad1990@gmail.com

Abstract. Acute coronary syndrome (ACS) is a serious clinical manifestation of coronary artery disease and is the major cause of morbidity and mortality worldwide. Established, that ACS and sudden death cause most IHD-related deaths, which represent 1.8 million deaths per year, with similar numbers of men and women dying from CAD. It is estimated that nearly half of patients with acute coronary syndrome (ACS) have one or more comorbid conditions, which have been linked to poor prognosis. The complexity of clinical decision-making in the presence of multiple comorbidities and the lack of explicit guidelines has been linked to poorer adherence to treatment protocols and worse outcomes for ACS patients. Under-usage of medication and standard-of-care procedures due to the unknown effects of certain therapies for patients with multiple comorbidities (e.g. percutaneous coronary interventions, dual antiplatelet therapy) and worse in-hospital and one year outcomes as well as increased mortality rates have been reported in ACS patients with multiple co-morbidites.

Trimetazidine is a second-line medication for treatment stable angina and microvascular angina in European and national guidelines. The efficacy and safety of trimetazidine in ACS patients are under investigation.

The purpose of research: to assess the short-term potential benefits and safety of trimetazidine added to standard evidence-based medical treatment in patients with ACS and co-morbidities: arterial hypertension and/or 2 type diabetes mellitus.

Materials and Methods. We observed of 184 patients with ACS with arterial hypertension (AH) and / or 2 type diabetes (DM). The diagnosis was verified by laboratory and instrumental methods according to European Society of Cardiology guidelines $(2017,2020)$ [10,11]. All patients were divided into four groups: $1^{\text {st }}$ group - 42 patients with ACS without AH or DM; $2^{\text {nd }}$ group - 56 patients with ACS and previous AH; $3^{\text {rd }}$ group -42 patients with ACS and 2 type DM; and $4^{\text {th }}$ group -44 patients with ACS and AH and DM. Due to the treatment strategy patients from each group were divided into 2 subgroups: a - with guidelines-recommended therapy (GRT) and b - with GRT and trimetazidine (TMZ) $35 \mathrm{mg}$ twice a day. The following laboratory tests were performed, in our trial: blood glucose, HbA1c, serum urea, serum creatinine, total cholesterol, low-density lipoprotein (LDL) cholesterol, high-density lipoprotein (HDL) cholesterol, triglyceride, serum sodium, serum potassium, CRP, cardiac troponin I, NT-proBNP.

Results. The mean age of all observed patients with ACS was 64.6 \pm 11.9 years; 93 (50.5\%) were males and 91 (49.5\%) females among them (see table 1). ACS without persistent ST segment elevation was diagnosed in 44 (23.9\%) cases; instead ACS with persistent ST segment elevation - in $140(76.1 \%)$ cases. In all trimetazidine treatment groups, the weekly frequency of angina symptoms showed the significant reductions at 28-day visit compared with baseline $(\mathrm{p}<0.05)$. Similar, the short-acting nitrate consumption was significant low during the course of treatment with trimetazidine $(p<0.05)$. Additional prescription of trimetazidine had significant effects for decrease of glucose, LDL cholesterol, CRP and NT-proBNP levels in patients with ACS and co-morbidities. Any serious adverse events were detected in the trimetazidine groups or in the placebo groups.

Conclusions. Additional prescription of trimetazidine has significant effects for decrease of glucose, LDL cholesterol, CRP and NT-proBNP levels in patients with ACS and arterial hypertension and/or 2 type diabetes mellitus and has good safety.

Keywords: acute coronary syndromes, hypertension, diabetes mellitus, trimetazidine.

Introduction. Acute coronary syndrome (ACS) is a serious clinical manifestation of coronary artery disease (CAD) and is the major cause of morbidity and mortality worldwide. Established, that ACS and sudden death cause most IHD-related deaths, which represent 1.8 million deaths per year, with similar numbers of men and women dying from CAD [1].

It is estimated that nearly half of patients with acute coronary syndrome (ACS) have one or more comorbid conditions, which have been linked to poor prognosis. The complexity of clinical decision-making in the presence of multiple comorbidities and the lack of explicit guidelines has been linked to poorer adherence to treatment protocols and worse outcomes for ACS patients [2]. Under-usage of medication and standard-of-care procedures due to the unknown effects of certain therapies for patients with multiple comorbidities (e.g. percutaneous coronary interventions, dual antiplatelet therapy) and worse in-hospital and one year outcomes as 
well as increased mortality rates have been reported in ACS patients with multiple co-morbidites [3].

In the past decades, diagnostic and therapeutic strategies for these patients have substantially improved. This includes faster and more accurate diagnostic algorithms, which are based on high-sensitivity cardiac troponin; improved therapeutic options, as modern drugeluting-stents, potent P2Y12 inhibitors and lipidlowering drugs [3].

Rationale for the research. Trimetazidine (1(2,3,4-trimethoxybenzyl) piperazine) is a cellular antiischemic agent with selectively inhibition of the final enzyme of the fatty acid oxidation pathway 3ketoacylcoenzyme A thiolase activity. Administration of this drug leads to a switch in preference of the energy substrate, resulting in partial inhibition of fatty acid oxidation and increased glucose oxidation [4]. Several clinical trials had shown that trimetazidine has cardioprotective effects in the setting of myocardial ischemia. This drug exerts no effect on coronary flow, contractility, blood pressure, or heart rate; it has no significant negative inotropic or vasodilatory properties at rest or during exercise; therefore, it can be excellently combined with conventional pharmacotherapy of CAD [5].

Trimetazidine is a second-line medication for treatment stable angina and microvascular angina in European and national guidelines. The meta-analysis of trimetazidine in angina pectoris included 23 studies with 1378 patients involved was shown to reduce by about $40 \%$ the mean number of weekly angina attacks compared with placebo $[-1.44 \quad(95 \%$ CI: -2.10 to $-0.79)]$; reduce of the weekly consumption of nitroglycerin tablets [-1.47 (95\% CI: -2.20 to -0.73$)$ ] and increased the exercise time to $1-\mathrm{mm}$ ST-segment depression [0.32 (95\% CI: $0.15-0.48)]$. These modest benefits were apparent independently of whether trimetazidine was given as monotherapy or combined with another antianginal agent [6].

Other meta-analysis of 11 randomized controlled trials was shown that trimetazidine can significantly improve left ventricular ejection fraction (LVEF) $[6.88 \%$ (95\% CI: 5.50 to 8.25$)$ ], reduce left ventricular endsystolic volume [11.58 mL (95\% CI: 5.79 to 17.37$)$ ], and wall motion score index [0.23 (95\% CI: 0.07 to 0.38$)$ ] [7].

In elderly patients with multivessel coronary heart disease and diabetes mellitus after drug-eluting stent implantation and on 2-year follow-up, trimetazidine showed significant improvements in the incidence $(p=0.024)$ and severity of angina pectoris, compared with the control group, as well as silent myocardial ischemia $(p=0.009)$ and angina pectoris free survival $(p=0.011)$. LV function and structure in trimetazidine-treated patients were relatively stable at 2-year follow-up, whereas they deteriorated in the control group with a significant difference between groups (all $\mathrm{p}<0.01)$ [8].

In small prospective trial the oral trimetazidine usage in diabetic patients receiving thrombolytic therapy for anterior wall ST-segment elevation myocardial infarction (STEMI) was associated with less myocardial damage, earlier successful reperfusion, improvement of LVEF and less cardiac adverse events [4]. In other hand, the newest randomised, double-blind, placebo-controlled, event-driven trial of trimetazidine added to standard background therapy in patients who had undergone successful PCI at 365 centres in 27 countries across Europe, South America, Asia, and north Africa showed that the routine use of oral trimetazidine $35 \mathrm{mg}$ twice daily over several years in patients receiving optimal medical therapy, after successful PCI, does not influence the recurrence of angina or the outcome; these findings should be taken into account when considering the place of trimetazidine in clinical practice [9].

The purpose of research: to assess the shortterm potential benefits and safety of trimetazidine added to standard evidence-based medical treatment in patients with ACS and co-morbidities: arterial hypertension and/or 2 type diabetes mellitus.

Materials and Methods. We observed of 184 patients with ACS in period from 1 January 2020 to 30 December 2020, which were hospitalized at IvanoFrankivsk Regional Cardiology Center or IvanoFrankivsk Central City Hospital (Ukraine). The diagnosis was verified by laboratory and instrumental methods according to European Society of Cardiology guidelines $(2017,2020)[10,11]$. All patients were divided into four groups: $1^{\text {st }}$ group - 42 patients with ACS without $\mathrm{AH}$ or $\mathrm{DM} ; 2^{\text {nd }}$ group - 56 patients with ACS and previous $\mathrm{AH}$; $3^{\text {rd }}$ group -42 patients with ACS and 2 type DM; and $4^{\text {th }}$ group -44 patients with ACS and AH and DM.

Due to the treatment strategy patients from each group were divided into 2 subgroups: a - with guidelinesrecommended therapy (GRT) and b - with GRT and trimetazidine (TMZ) $35 \mathrm{mg}$ twice a day. No significant difference in baseline characteristics between patients groups was observed (table 1). The following laboratory tests were performed, in accordance with applicable protocols, at visit one (patient' admission) and visit at 28 day after ACS onset: blood glucose, HbAlc, serum urea, serum creatinine, total cholesterol, low-density lipoprotein (LDL) cholesterol, high-density lipoprotein (HDL) cholesterol, triglyceride, serum sodium, serum potassium, CRP, cardiac troponin I, NT-proBNP.

The research was performed in accordance with the Helsinki Declaration and Good Clinical Practice Guideline. The research was approved by the local ethics committee and written informed consent was obtained from all patients. Categorical variables are presented as percentages, whereas continuous variables are presented as mean (M) and standart error of mean (m) if normally distributed, or as median and interquartile range (Me [IQR]), if not. Categorical variables were compared by the $\chi^{2}$ test and continuous variables by the $t$ test or the Mann-Whitney U test. A $p$ value of $<0.05$ was considered statistically significant. All tests were 2-sided. Analyses were performed with Statistica system software, version 12.0.

Results. The mean age of all observed patients with ACS was $64.6 \pm 11.9$ years; $93(50.5 \%)$ were males and 91 (49.5\%) females among them (see table 1). ACS without persistent ST segment elevation was diagnosed in $44(23.9 \%)$ cases; instead ACS with persistent ST segment elevation - in $140(76.1 \%)$ cases. The mean duration of time interval from the onset of heart attack symptoms to admission in emergency unit was 02:23'(02:07') (h:m [SD]). 


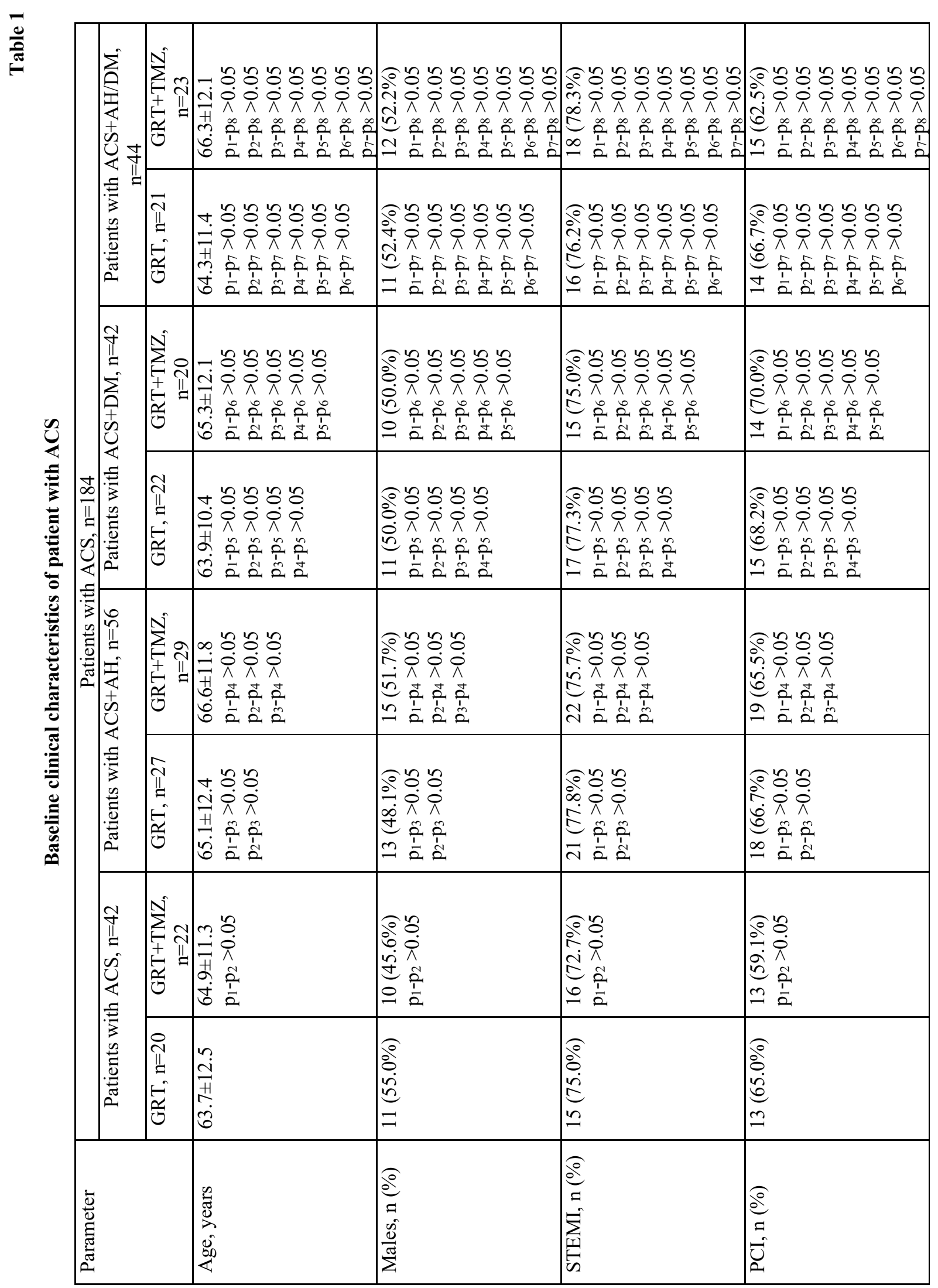




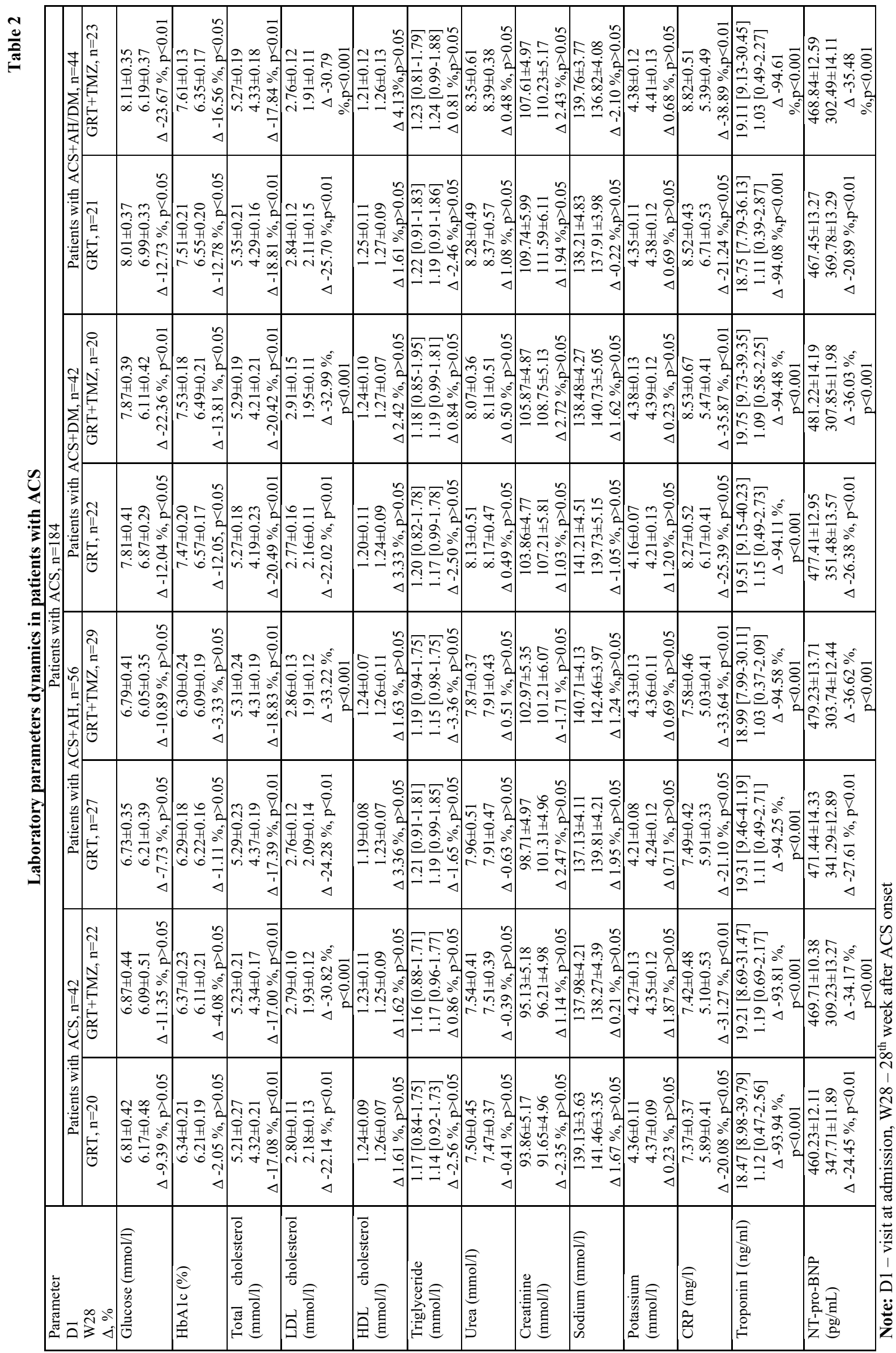


In all trimetazidine treatment groups, the weekly frequency of angina symptoms showed significant reductions at 28 day visit compared with baseline $(\mathrm{p}<0.05)$. Similar, the short-acting nitrate consumption was significant low during the course of treatment with trimetazidine $(\mathrm{p}<0.05)$.

Additional prescription of trimetazidine had significant effects for decrease of glucose, LDL cholesterol, CRP and NT-proBNP levels in patients with ACS and comorbidities (table 2).

Any serious adverse events were detected in the trimetazidine groups or in the placebo groups.

Discussion. Our clinical data showed that the addition of TMZ to conservative treatment profoundly down regulated the risk of coronary heart disease, as indicated by the suppression of CRP and NT-proBNP in patients with ACS. In secondary analysis of the VISTA16 randomized clinical trial that included 5145 patients, baseline and longitudinal high-sensitivity C-reactive protein levels were independently associated with increased risk of a major adverse cardiac event, cardiovascular death, and all-cause death during the 16week follow-up [12]. Many recent studies, including Clopidogrel as Adjunctive Reperfusion TherapyThrombolysis in Myocardial Infarction 28 (CLARITYTIMI 28) study, have demonstrated BNP or NT-proBNP measurements to be a strong predictor of adverse outcome in patients with ACS [13]. In other hands, in trial of 1079 ACS patients was the lack of an association between NT-proBNP concentrations and prognosis in any models tested by Cox proportional hazards survival analyses [14].

Our clinical results also suggest that TMZ exhibits significantly elevated HDL-cholesterol levels and patented of glucose-lowering drugs effects. Recent meta-analysis of PubMed, EMBASE, and Cochrane databases between the inception dates of databases and May 2019 showed that additional TMZ treatment significantly decreased fasting blood glucose, glycosylated hemoglobin level, serum level of total cholesterol, low-density lipoprotein cholesterol and incidence of myocardial ischemia episodes. However, there were no significant differences in serum triglyceride level, high-density lipoprotein cholesterol, exercise tolerance between the TMZ group and the control group [15].

Conclusions. Additional prescription of trimetazidine has significant effects for decrease of glucose, LDL cholesterol, CRP and NT-proBNP levels in patients with ACS and arterial hypertension and/or 2 type diabetes mellitus and has good safety.

\section{References:}

1. Townsend N, Wilson L, Bhatnagar P, Wickramasinghe $\mathrm{K}$, Rayner $\mathrm{M}$, Nichols $\mathrm{M}$. Cardiovascular disease in Europe: epidemiological update. Eur Heart J. 2016; 37:3232-45.

2. Burke LA, Rosenfeld AG, Daya MR, et al. Impact of comorbidities by age on symptom presentation for suspected acute coronary syndromes in the emergency department. Eur J Cardiovasc Nurs. 2017; 16(6):511521.
3. Cimci M, Witassek F, Radovanovic D, Rickli H, Pedrazzini GB, Erne P, Müller O, Eberli FR, Roffi M. Temporal trends in cardiovascular risk factors' prevalence in patients with myocardial infarction. Eur J Clin Invest. 2021; 51(4):e1.

4. Shehata M. Cardioprotective Effects of Oral Trimetazidine in Diabetic Patients With Anterior Wall Myocardial Infarction Treated with Thrombolysis. Cardiol Res. 2014; 5(2):58-67.

5. Dézsi Csaba A. Trimetazidine in Practice. American Journal of Therapeutics. 2016; 23(3):e871-e879.

6. Ciapponi A, Pizarro R, Harrison J. Trimetazidine for stable angina. Cochrane Database Syst Rev. 2005; 4:CD003614

7. $\mathrm{Hu} \mathrm{B}, \mathrm{Li} \mathrm{W}, \mathrm{Xu} \mathrm{T}$, Chen T, Guo J. Evaluation of trimetazidine in angina pectoris by echocardiography and radionuclide angiography: a meta-analysis of randomized, controlled trials. Clin Cardiol. 2011; 34(6):395-400.

8. Xu X, Zhang W, Zhou Y, Zhao Y, Liu Y, Shi D, Zhou Z, Ma H, Wang Z, Yu M, Ma Q, Gao F, Shen $\mathrm{H}$, Zhang J. Effect of trimetazidine on recurrent angina pectoris and left ventricular structure in elderly multivessel coronary heart disease patients with diabetes mellitus after drug-eluting stent implantation: a single-centre, prospective, randomized, double-blind study at 2-year follow-up. Clin Drug Investig. 2014; 34(4):251-8.

9. Ferrari R, Ford I, Fox K, Challeton JP, Correges A, Tendera M, Widimský P, Danchin N; ATPCI investigators. Efficacy and safety of trimetazidine after percutaneous coronary intervention (ATPCI): a randomised, double-blind, placebo-controlled trial. Lancet. 2020; 396(10254):830-838.

10. Ibanez B, James S, Agewall S, Antunes MJ, Bucciarelli-Ducci C, et al; ESC Scientific Document Group. 2017. ESC Guidelines for the management of acute myocardial infarction in patients presenting with ST-segment elevation: The Task Force for the management of acute myocardial infarction in patients presenting with ST-segment elevation of the European Society of Cardiology (ESC). Eur Heart J. 2018, Jan 7; 39(2):119-177.

11. Collet JP, Thiele H, Barbato E, Barthélémy O, Bauersachs J, et al; ESC Scientific Document Group. 2020. ESC Guidelines for the management of acute coronary syndromes in patients presenting without persistent ST-segment elevation. Eur Heart J. 2021;42(14):1289-1367

12. Mani P, Puri R, Schwartz GG, et al. Association of Initial and Serial C-Reactive Protein Levels With Adverse Cardiovascular Events and Death After Acute Coronary Syndrome: A Secondary Analysis of the VISTA-16 Trial. JAMA Cardiol. 2019; 4(4):314320. O'Donoghue ML, Morrow DA, Cannon CP, Jarolim P, Desai NR, Sherwood MW, Murphy SA, Gerszten RE, Sabatine MS. Multimarker Risk Stratification in Patients With Acute Myocardial Infarction. J Am Heart Assoc. 2016; May, 20; 5(5):e002586.

13. Suzuki T, Heaney LM, Jones DJ, Ng LL. Trimethylamine N-oxide and Risk Stratification after 
Acute Myocardial Infarction. Clin Chem. 2017; Jan, 63(1):420-428.

14. Lin Ye,Wang Zhenlian,Yan Min,Zhu Feiyu,Duan Ye,Sun Zhiqin. Effect of Trimetazidine on Diabetic Patients with Coronary Heart Diseases: A MetaAnalysis of Randomized, Controlled Trials. Chinese Medical Sciences Journal. 2020; 35(3):226-238.

\section{УДК 616.127-005.8+616.035.1 ЕФЕКТИВНІСТЬ ТРИМЕТАЗИДИНУ В ПАЦІЕНТІВ ІЗ ГОСТРИМИ КОРОНАРНИМИ СИНДРОМАМИ ТА КОМОРБІДНИМИ СТАНАМИ}

\section{І.П. Вакалюк, Ійад Альзгаві}

Івано-Франківський національний медичний університет, кафедра внутрішньої медицини №2 та медсестринства, м. Івано-Франківськ, Україна, ORCID ID: 0000-0002-4430-6816, ORCID ID: 0000-0002-4280-917X, e-mail: eyadeyad1990@gmail.com

Резюме. Гострі коронарні синдроми (ГКС) серйозний клінічний прояв ішемічної хвороби зі значним поширенням та смертністю в усьому світі.

Мета. Оцінити короткотерміновий потенційний вплив та безпеку триметазидину в додаток до оптимальної медикаментозної терапії в хворих на ГКС та супутні артеріальну гіпертензію (АГ) та цукровий діабет 2 типу (ЦД).

Матеріали та методи. Обстежені 184 пацієнтів із ГКС та супутніми АГ та/чи ЦД 2 типу. Відповідно до терапевтичної стратегії пацієнти кожної 3 груп були розділені на 2 підгрупи: із терапією, відповідно до настанов, та 3 додатковим призначенням триметазидину по 35 мг двічі в день. Проводили визначення наступних показників: глюкоза, глікозильований гемоглобін (HbA1c), сечовина, креатинін, показники ліпідограми, сироватковий натрій, сироватковий калій, C-реактивний протеїн (CRP), серцевий тропонін I, попередник мозкового натрій-уретичного пептиду (NT-proBNP).

Результати. В усіх групах обстеження додаткове призначення триметазидину зменшувало частоту нападів стенокардії наприкінці дослідження, порівняно з групою плацебо ( $<0.05)$. Подібно, вірогідно зменшувалася потреба у вживанні короткодіючих нітратів $(\mathrm{p}<0.05)$. Додаткове призначення триметазидину чинило вірогідні потенціюючи ефекти на зменшення рівнів у крові глюкози, холестерину ліпопротеїдів низької густини (XC ЛПНГ), CRP та NTproBNP.

Висновки. Додаткове призначення триметазидину володіє додатковим впливом на зменшення рівнів у крові глюкози, ХC ЛПНГ, CRP таNT-proBNP у хворих на ГКС із супутніми АГ та/чи ЦД 2 типу; володіє відмінним профілем безпеки.
Ключові слова: гострі коронарні синдроми, артеріальна гіпертензія, цукровий діабет, триметазидин.

\section{УДК 616.127-005.8+616.035.1 \\ ЭФФЕКТИВНОСТЬ ТРИМЕТАЗИДИНА В ПАЦИЕНТОВ С ОСТРЫМИ КОРАНАРНЫМИ СИНДРОМАМИ И КОМОРБИДНЫМИ СОСТОЯНИМИ}

\section{И.П. Вакалюк, Ийад Альзгави}

Ивано-Франковский нацииональный медицинский университет, кафедра внутренней медицины и медсестринства, г. Ивано-Франковск, Украина, ORCID ID: 0000-0002-4430-6816,

ORCID ID: 0000-0002-4280-917X,

e-mail: eyadeyad1990@gmail.com

Резюме. Острые коронарные синдромы (ОКС) - серьезное клиническое проявление ишемической болезни сердца с широкой распространенностью и смертностью в мире.

Цель. Оценить краткосрочное влияние и безопасность триметазидина в дополнение к оптимальной медикаментозной терапии больных из ОКС и артериальной гипертензией (АГ) и/или сахарным диабетом (СД) 2 типа.

Материалы и методы. Обследованы 184 пациентов из ОКС и сопутствующими АГ и/или СД 2 типа. В зависимости от терапевтической стратегии больные каждой из групп были разделены на 2 подгруппы: из терапией в соответствии с рекомендациями, и с дополнительным приемом триметазидина по 35 мг два раза в день. Определяли следующие показатели: глюкоза, гликозилированый гемоглобин (HbA1c), мочевина, креатинин, показатели липидограммы, сывороточный натрий, сывороточный калий, C-реактивный белок (CRP), сердечный тропонин I, мозговой натрий-уретический пептид (NT-proBNP).

Результаты. Во всех группах отмечали, что дополнительное назначение триметазидина уменьшало частоту приступов стенокардии в конце исследования, в сравнении с группой плацебо $(\mathrm{p}<0.05)$. Аналогично, уменьшалась необходимость приема нитратов коротокого действия $(\mathrm{p}<0.05)$. Допольнительное назначений триметазидина потенцировало уменьшение в крови уровней глюкозы, холестерина липопротеидов низкой плотности (ХС ЛПНП), CRP и NTproBNP.

Выводы. Дополнительное назначение триметазидина имеет дополнительное влияние на уровни в крови глюкозы, ХC ЛПНП, CRP и NT-proBNP у больных из ОКС и АГ и/или СД 2 типа.

Ключевые слова: острый коронарный синдром, артериальная гипертензия, сахарный диабет, триметазидин. 